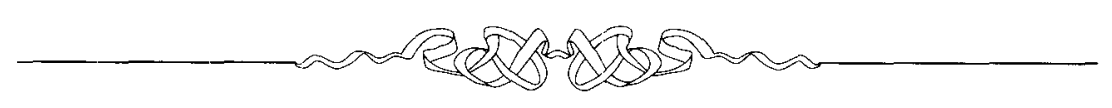

PAUL CRUMBLEY

\title{
Art's Haunted House: Dickinson's Sense of Self
}

I riting to Dickinson in 1869 , the year before he met the poet in Amherst, Thomas Wentworth Higginson describes the discomfort that Dickinson's haunting presence could inflict on a man fully at home in domesticated art: "Sometimes I take out your letters \& verses, dear friend, and when I feel their strange power, it is not strange that I find it hard to write ..." (L461, \#330a). Dickinson's writing, Higginson continues, provides him no clear target for his words: "I should like to hear from you very often, but feel always timid lest what I write should be badly aimed \& miss that fine edge of thought which you bear. . . I I think if I could once see you \& know that you are real, I might fare better." But when actually confronted with Dickinson's physical presence, Higginson had no better luck in reaching the heart of her mystery. Describing that first meeting more than twenty years after the fact, in an account published in the October 1891 issue of the Atlantic Monthly, Higginson reveals what he could not feel from the poet's "reality" — that stable sense of self he sought:

She was much too enigmatical a being for me to solve in an hour's interview, and an instinct told me that the slightest attempt at direct crossexamination would make her withdraw into her shell; I could only sit still and watch, as one does in the woods; I must name my bird without a gun .... (L476, \#342b)

Though Higginson admits here that he cannot "solve" the poet, his language implies a primary assumption that identity can be solved, given world enough and time. The metaphor of the "shell," particularly, suggests that for Higginson, however enigmatic the self's outward expression, it exists ultimately as a kernel of reality housed in a specific locale. Paralyzed in the face of such elusiveness, Higginson "could only sit and watch," 
though he wished for a cessation of movement, a stabilization of the sort a gun would provide. Even in the flesh, Dickinson refuses to become Higginson's target; in fact, he cannot so much as "name [his] bird."

I want to argue here that Higginson's discomfort provides a clue to Dickinson's poetics. Unbeknowst to himself, Higginson had entered the haunted house which Dickinson's art and much of her life had become. Dickinson's 1876 letter to him that defines "Art" as "a House that tries to be haunted" (L554, \#459 ${ }^{\mathrm{A}}$ ) suggests the poet's interest in discovering language appropriate to a self that moves through, but is not contained by, any particular linguistic, social, religious or material habitation. The ghostly insubstantiality that so troubled Higginson indicates he had discovered the phantoms Dickinson preferred over the solidity of a unified self. Higginson's discomfort corresponds to the vertiginous disorientation Dickinson describes in 1870 as a distinguishing property of poetry: "it makes my whole body so cold no fire can warm me," she told him; it makes her "feel physically as if the top of my head were taken off" (L473-474, \#342a). In Dickinson's writings, metaphors related to haunting, homelessness, and being at sea describe the dislocations central to a poetic project dedicated to sustaining a self sufficiently insubstantial or "ghostly" to elude containment, whether it be in the house of one's father, God's creation, or the architecture of poetic convention.

I will start by describing what motivates this strategy - the fear of entrapment by social and linguistic conventions - as it is defined in almost parable form through Dickinson's many allusions to Lord Byron's poem "The Prisoner of Chillon." In this poem, a political rebel grows so accustomed to imprisonment that he ceases to distinguish between freedom and the confinement of his cell. For Dickinson the poem becomes a paradigm for the unconscious surrender of self in a prison of its own creation. "You remember the Prisoner of Chillon," she writes her sister Lavinia, who "did not know Liberty when it came, and asked to go back to Jail" (L433, \#293). Dickinson uses this model of unconscious surrender in the many poems that present house, home, and marriage as sites of imprisonment, prisons which entrap unwitting women in limiting, domestic identities. The bewildered speaker of "Doom is the House without / the Door" details her life as a domestication so devastatingly complete that even her dreams conform:

'Tis varied by the Dream

Of what they do outside -

When Squirrels play — and

(low, downward)

Berries die -

And Hemlocks — bow - to

God -

(P475, MBED 802) 
The speaker of "How soft this Prison is" (P1334, no ms.) expresses the dangerous familiarity of imprisoning homes: "A Dungeon but a Kinsman is / Incarceration - Home." The Bride of "A Wife - at Daybreak - / I shall be -" (P461, MBED 781), who expects to be transformed through marriage, states her dismay at discovering not newness but a "face" she has "seen" "before." The point Dickinson makes in these and hundreds of poems like them is that speakers unknowingly contribute to their own social entrapment.

Dickinson then suggests that we view the disorientation felt upon discovering our complicity not only as normal, but as desirable. Physical, emotional, philosophical discomfort, that is, must be accepted as integral to a more expansive experience of selfhood. Dickinson's poetry tells us that living with those sensations of discomfort most of us have been conditioned to avoid may be the only way to sustain and accommodate a self strong enough to resist the promise of comfort held out by socially assigned roles.

What can be called a strategy for the proper orientation of the self is laid out in the fifth poem of her first fascicle, "We lose — because we win - " (P21, MBED 5):

We lose - because we win -

Gamblers - recollecting which - (low, downward)

Toss their dice again!

The word "again" that concludes the poem makes it clear that the recollection mentioned in the second line occurs while a game is underway. "Gamblers," then, are those who remain cognizant of the need for all players to accept, and continually re-accept, a standardized set of rules that allow for both winning and losing. The poem seems particularly designed to remind those who are losing that the same logic dictating present loss also makes possible future victories. In this way the poem acts as a parable about the provisional character of identity; losers turn into winners, and visa versa, continuously, the status of either identity never more than a partial reflection of a larger self capable of playing many different games.

When "losing" and "winning" are seen as the "Gambler's" sequential identities, the poem can be said to lay out a three-staged approach to identity formation. The poem's first line acknowledges that rules govern all types of play (identity formation); we only "win" because we also "lose." Secondly, as gamblers recollect the fact that their identities as winners or losers are authorized by prior assent to the rules of the game, so we must recognize identity as a provisional housing of the self also contingent upon personal assent. Finally, like the gamblers, we can all joyously enter or reenter games once armed with the knowledge that we determine the rules and therefore hold a part of ourselves aloof from whatever identity we 
choose. Players who forget become like the prisoner of Chillon; those who "recollect" their initial assent, however, retain a sense of self prior to the game and remain free to reenact their initial decision to play: these "Gamblers" toss their dice knowing that victory and loss are both functions of a "player" identity they have temporarily assumed.

In numerous poems, Dickinson elaborates the gambler's deliberate dislocations of self with metaphors of homelessness, haunting and the sea, instilling in her writing the anxiety that accompanies delight in the gambler's roll of the dice. Homelessness - the refusal to inhabit permanently the rules of any game - becomes the condition most desired by the poet. In "To learn the Transport by the Pain" (P167, MBED 133), for instance, her speaker describes the "signal wo" of "patient 'Laureates'" who

$$
\begin{aligned}
& \text { stay [their] homesick - homesick feet } \\
& \text { Upon a foreign shore - } \\
& \text { Haunted by native lands, the while - }
\end{aligned}
$$

The poem presents as desirable a "transport" accepted by poets who choose homelessness. Dickinson's spring 1883 letter to Maria Whitney contains a poem in which the uncertainty that accompanies the loss of a loved one stimulates a creative "Fashioning" and "Fathoming" that "dissolves the days / Through which existence strays / Homeless at home" (L771, \#815; P1573). "A nearness to Tremendousness - ," on the other hand, alerts readers that proximity to power can bring painful dislocations:

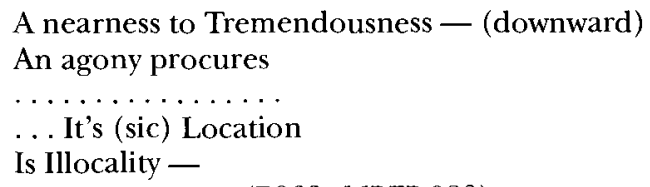

(P963, MBED 980)

As Dickinson's July 1878 letter-poem to Sarah Eliza Tuckerman makes clear, she considered the discomfort provoked by such tremendousness desirable, despite the need to approach it with care:

Go not too near a House of Rose -

The depredation of a Breeze

Or inundation of a Dew

Alarm it's walls away -

Nor try to tie the Butterfly,

Nor climb the Bars of Ecstasy,

In insecurity to lie

Is Joy's insuring quality.

(P1434; L614, \#558, ACL) 
All four of these poems promote the idea that continued participation in the larger universe is possible only when the perceptual locus is uncertain when poet, speaker, or reader are homeless in language.

That such uncertainty need not be tragic is made clear in several letters elaborating the way pain and regret are balanced by the "Joy" in "insecurity" alluded to in the gambler's decision to "toss [the] dice again." In these letters Dickinson frequently uses the metaphor of the sea to describe this "Joy": "Moving on in the Dark like Loaded Boats at Night, though there is no Course, there is Boundlessness -" (L800, \#871), she writes in October 1883. In another letter, probably written in late 1885, Dickinson views the sea's boundlessness as both a source of life and a means for perpetuating it: "Emerging from an Abyss, and reentering it - that is Life, is it not, Dear?" (L893, \#1024). With these words, Dickinson briefly identifies past encounters with disorientation that for her had become a life-affirming pattern. Crucial to this pattern is both an emergence out of obliteration and the acceptance of a future return to it. Life is positioned on the verge of the "Abyss," making that edge a figurative locus for experience.

I want to end by considering how these strategies of discomfort, expressed in metaphors of imprisonment, homelessness, gambling, haunting, arid the sea, can change our sense of the third Master Letter, a text usually read as, in Martha Nell Smith's words, "pleadings" that "seem to certify Dickinson's feminine frailty" (100). The letter opens with Dickinson's figurative description of herself as a bird shot by a gun. The image, though it seems to begin as a plea for sympathy from her correspondent, is tinged with fierceness at the end of the opening passage, a fierceness that hints that something more powerful than a wounded bird lurks in the heart of the writer: "If you saw a bullet hit a Bird ... One drop more from the gash that stains your Daisy's bosom - then would you believe?" (The Master Letters of Emily Dickinson 32). Despite the ambivalent tone, the bird metaphor appears to signal Dickinson's entrapment in the emotionally dependent role her society assigned women. For the next two-and-a-half pages, the letter is plaintively humble and self-effacing. "I didn't be myself - Master - I dont know how it was done," she writes, and "I knew you had altered me —" (35); finally, "You make me say it over — I fear you laugh -- when I do not see" (36).

But at this point the language of the letter changes, a shift signalled by the terse though pregnant statement, "Chillon is not funny." With these words, Dickinson seems to identify the prison into which she had drifted in the first pages of the letter, recognizing at last that it is a prison constructed with her prior assent. Dickinson now steps out of dependency and into an entirely different, altogether more authoritative voice. She 
speaks suddenly as an adult, equal to the Master, capable of mockery and disdain: "Have you the Heart in your breast - Sir — is it set like mine - a little to the left - has it the misgiving - if it wake in the night - perchance - itself to it - a timbrel is it - itself to it a tune?" (36). All deferential bowing has ended; her heart, her body has become the standard against which the other is measured. At the moment of seizing authority, Dickinson's self temporarily takes on a positive location, defined by her physical presence. From this bodily centered site of authority Dickinson now instructs where she had previously pleaded - "These things are [reverent] holy, Sir"; she also becomes mockingly accusatory: "You say I do not tell you all - Daisy confessed - and denied not" (39). But as the letter progresses, Dickinson does not let herself remain in the centered state which could make her yet again the bird-like target for a gun. Now the imperial poet speaks, proclaiming the power language possesses to transform those who hear it. As if issuing a warning to her reader, she ominously declares that her words may prove more than the other can handle: "Vesuvius dont talk - Etna - dont — one of them — said a syllable - a thousand years ago, and Pompeii heard it, and hid forever - She could'nt look the world in the face, afterward...."

In the climactic fourth page, Dickinson positions herself as a volcanic presence whose expanding circumference rises within the illocality of the sea and acknowledges no limit but that posed by her own visual horizon. She asks, "you have felt the Horizon — hav'nt you — and did the sea never come so close as to make you dance?" Again, the tone seems to be both mocking and instructive, as if stating that when writing - as she is out of illocality, her language acquires provisional meaning through perceptual horizons that alter as her circumference expands, leading her to "dance" from voice to voice. She wonders, with disdainful delight, if her correspondent has ever experienced such a thing.

Higginson may well have had a hard time holding the fine edge of Dickinson's mind by this stage of her letter, had it been sent to him. Whatever hope the image of the bird may have afforded him at the beginning would almost certainly have been lost by the time she got to Vesuvius and Etna. Unfortunately, Higginson's determination to identify a core identity appears to have prevented him from enjoying the remarkably intimate dance that Dickinson's writing offers. As she wrote her close friend Elizabeth Holland in January 1881, hers was a "Gymnastic Destiny" (L687, \#685). "I knew a Bird," she teased in that letter, "that would sing as firm in the centre of Dissolution, as in it's Father's nest - Phenix or the Robin? While I leave you to guess, I will take Mother her tea -." She closes the third Master Letter with a similar riddle, transforming the solid-seeming wounded bird 
with which she began into something less substantially a bird but more fully capable of ghostly flight through nature's haunted house: "No Rose, yet felt myself / a'bloom / No Bird - yet rode in Ether -" (MLED 44). Higginson never had any chance of successfully naming this bird. 